\title{
An unusual manifestation of a breast mass: primary lymphoma
}

\author{
Majid Montazer ${ }^{1 *}$, Maryam Hoseini ${ }^{2}$ and Haleh Farzin ${ }^{3}$
}

*Correspondence: Montazerma@tbzmed.ac.ir

\author{
CrossMark
}

- Click for updates

\begin{abstract}
${ }^{1}$ Assistant Professor of Thoracic Surgery Department, Tabriz University of Medical Sciences, Iran. ${ }^{2}$ Assistant of Anesthesiology, Tabriz University of Medical Sciences, Iran.

${ }^{3}$ Assistant of Anesthesiology, Tabriz University of Medical Sciences, Iran.
\end{abstract}

\begin{abstract}
Background: Some of breast masses are uncommon including primary diffuse primary large B-cell lymphoma. It is commonly seen in pregnant and lactating women. It has usually unpleasant symptoms and referred with unspecified diagnosis. The confirmation of diagnosis made by biopsy and patient benefit from radiotherapy and chemotherapy.

Methods and materials: In this literature, we report a 41 years old women with several masses in her lactation duration. She had history of 3 cesarean section and seemingly, normal course of pregnancy. Her major chief compliant was painless masses in her breast that initially diagnosed as mastitis.

Conclusion: We concluded that occasionally some relatively rare disease such as primary breast lymphoma occurs with unrelated features. Likely, exact obtaining history and physical examination or timely using of imaging and pathology modalities can play important role and help us in guiding treatment.
\end{abstract}

Keywords: Breast cancer, lymphoma, unusual

\section{Introduction}

Primary lymphoma in breasts is a rare event.Lymphoepithelial lesions in ducts and lobules and vascular involvement have been seen in primary and secondary cases [1]. The bilateral diffuse type is reported in sporadic cases; it mostly affects pregnant and lactating women with large breasts [2]. The incidence of tumor was $0.04 \%$ to $0.5 \%$ and it mainly consists of large diffuse cells [3]. Diagnosis is made by biopsy and aspiration. Other beneficial tests are MRI and aspiration with cytology [4]. The patients cannot benefit from mastectomy, but biopsy or lumpectomy are beneficial contrast with biopsy or lumpectomy [5]. Unfortunately, this disease has not have a definite treatment but a combination of chemotherapy, radiotherapy and surgery is performed [6]. These tumors are commonly low grade and similar to nodal follicular masses [7]. Primary breast lymphoma is associated with poor outcome. Controlling the disease by radiotherapy and chemo therapy is beneficial but systemic relapses, as in the central nervous system (CNS), commonly occurs [8].

\section{Case presentation}

A 41-years old women referred to our clinic with the chief compliant of a palpable mass in the right breast. She had no previous considerable illness or drug history. She was a housewife and had history of 3 times cesarean section. On the first lactation day, she had found $2 \times 3 \mathrm{~cm}$ painless mass in the upper border of the right nipple which did not interfere with lactation. After 20 days, she found another painless mass in the left breast. Simultaneously, the size of breast enlarged. The baby refused breast feeding from the left breast. Both breasts were warm and erythematosus. Laboratory findings were as follows: Hemoglobin $(\mathrm{Hb})=10.6 \mathrm{~g} / \mathrm{dL}$, White blood cell(WBC) $=11.3 \times 10^{3} / \mathrm{mm}^{3}$, International normalized ratio $($ INR $)=1.1$, Prothrombin time $(\mathrm{PT})=12.7 \mathrm{~s}$, Partial thromboplastin time $(\mathrm{PTT})=$ $30 \mathrm{~s}$. Ultrasonography imaging reported increased thicknesses of cutaneous and subcutaneous layers of medial lobe of the right breast. Edema was manifested as fluid between tissue planes. Numerous hypo echoic areas with thick and irregular walls were observed throughout the breast which indicated abscesses; the largest one measured $77 \times 52 \times 47 \mathrm{~mm}^{3}$ and its volume was $99 \mathrm{~mL}$. The same findings were observed in the other breast. One of them was aspirated but there was not any collection of fluid in it. When infection was superimposed, 
Montazer et al., Breast Cancer Reports 2017,

http://www.hoajonline.com/journals/pdf/2057-1631-4-2.pdf

Cefazolin and Gentamicin were administered and then metronidazole and vancomycin were added.

Before the initiation of antibiotic consumption, the milk of both breast were send for culture and antibiogram, which reported staphylococcus. Laboratory findings were changed to $\mathrm{Hb}=11.9 \mathrm{~g} / \mathrm{dL}, \mathrm{WBC}=9.2 \times 10^{3} / \mathrm{mm}^{3}, \mathrm{INR}=1.1, \mathrm{PT}=12.7 \mathrm{~s}$, PTT $=30$ s. Magnetic resonance imaging (MRI) was requested but the patient did not consent to undergo it. Ultimately, she decided to discharge.

About one week later, she was readmitted to neurology ICU due to sudden weakness of lower extremities and urinary retention. The pathologic studies revealed intermediate grade of diffuse large B- cell lymphoma (Figure 1). Brain CT scan and brain and spine CT and MRI were obtained. In thoracic MRI infiltrative bone marrow lesion at T6 level was observed as isosignal to hyper-signal on T2-weighted and hypo-signal on T1-weighted. Paravertebral space was enlarged and aorta was shifted to lateral side. The mass extended longitudinally in this space and invaded T7-T8 vertebra. Cord impingement and myelopathy were noted at T5- T6 level (Figures 2 and 3). Plural effusion was noted bilaterally which was remarkable on the right side. The most likely diagnosis was metastasis. The patient underwent T6-T11 laminectomy and mass resection. The obtained samples were send to a pathologist. After a relative remission following two chemotherapy courses, she died due to pulmonary embolism.

\section{Discussion}

Lymphocytes exist commonly in breast, but lymphomas are rare [9] and have a localized form. They consists of less than $1 \%$ of NHL and $0.5 \%$ of breast tumors [10]. They are characterized by a primary lesion in breast, without any extra breast involvement [11]. Also, their presentation are as unilateral or

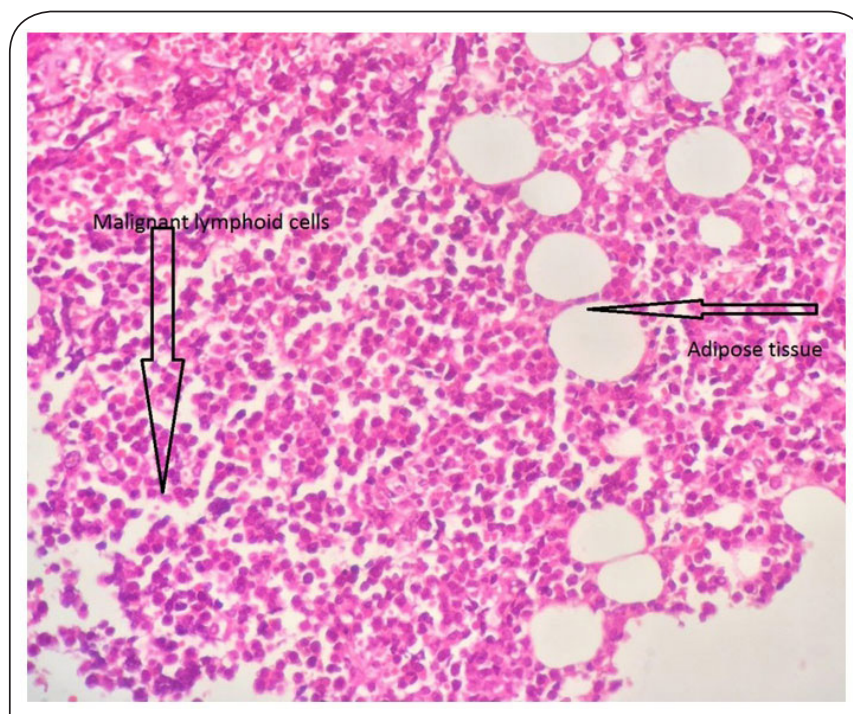

Figure 1. The horizontal arrow indicates the fat between the tissue of pathology and vertical hollow arrow indicates microscopic magnification by lymphocytic tumoral cells.

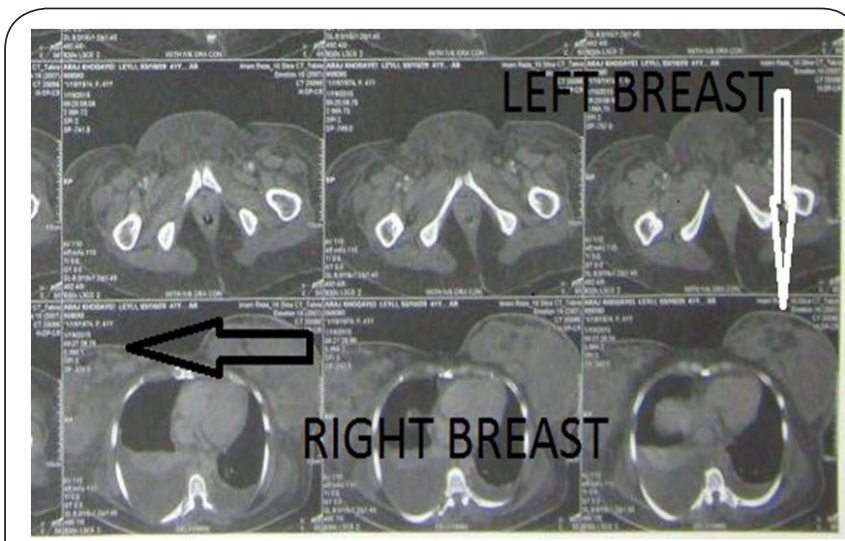

Figure 2. Vertical white arrow demonstrates tumoral involvement in left breast by congestive and multi loculated scheme and also hollow black arrow in the right corner shows the right breast tumor involvement.

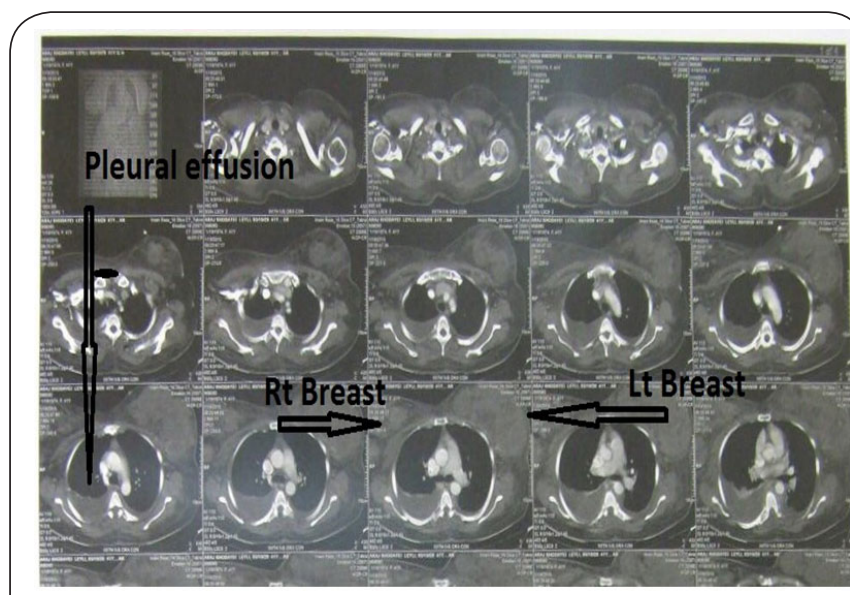

Figure 3. MRI image two horizontally arrows in the middle of the picture shows involvement of breasts with lymphoid tumor and accidentally in the right corner of the same picture the vertical arrow suggests pleural effusion in the right hemithorax.

bilateral but bilateral form and it is frequently in pregnant or lactating women [12]. Some authors showed mean age of 28 years old in $15 \%$ of pregnant or lactating women [13]. Clinical manifestations are as B symptoms: fever, weight loss and night sweats [14]. Between 1992 and 2012, 76 patients had the disease symptoms, Its most common feature is a diffuse large B-cell lymphoma(DLBCL)but other subtypes can also be seen [15]. There are a few investigations about treating and prognosis this type of disease $[16,17]$. Mastectomy is a sole modality that hasn't any significant impact on clinical course, so that patients should be benefit from immunotherapy [18], chemotherapy or radiotherapy $[10,19]$.

This article presents a report on a patient with breast mass that was finally diagnosed as breast lymphoma. A survey of literature revealed that this rare disease occurs as primary 
and secondary forms. But, this patient was first diagnosed with infectious diseases and mistreated with antibiotics. Her poor prognosis can be explained by a delay in true diagnosis and loss of golden time for precise work up as despite their undesirable side effects, chemotherapy, radiotherapy or combined approaches can be helpful in treating patients. However, no primary origin of tumors could be found and based on literature, these masses were supposed to be primary masses.

\section{Conclusion}

It can be concluded that, occasionally, some relatively rare diseases such as primary breast lymphoma occur with unrelated features. Likely, obtaining exact history and physical examination or timely using of imaging and pathology modalities can play an important role and be helpful in guiding treatment.

\section{Competing interests}

The authors declare that they have no competing interests.

\section{Authors' contributions}

\begin{tabular}{|l|c|c|c|}
\hline Authors' contributions & MM & MH & HF \\
\hline Research concept and design & $\checkmark$ & -- & -- \\
\hline Collection and/or assembly of data & -- & $\checkmark$ & -- \\
\hline Data analysis and interpretation & -- & -- & $\checkmark$ \\
\hline Writing the article & -- & -- & $\checkmark$ \\
\hline Critical revision of the article & $\checkmark$ & -- & -- \\
\hline Final approval of article & $\checkmark$ & -- & -- \\
\hline Statistical analysis & -- & -- & -- \\
\hline
\end{tabular}

\section{Publication history}

Editor: Wei-Hsiung Yang, Mercer University School of Medicine, USA.

Received: 07-Nov-2016 Final Revised: 24-Feb-2017

Accepted: 21-Mar-2017 Published: 04-Apr-2017

\section{References}

1. Cohen PL and Brooks JJ. Lymphomas of the breast. A clinicopathologic and immunohistochemical study of primary and secondary cases. Cancer. 1991; 67:1359-69. | Article | PubMed

2. Hugh JC, Jackson $\mathrm{Fl}$, Hanson J and Poppema S. Primary breast lymphoma. An immunohistologic study of 20 new cases. Cancer. 1990; 66:2602-11. | Article | PubMed

3. Pinheiro RF, Colleoni GW, Baiocchi OC, Kerbauy FR, Duarte LC and Bordin JO. Primary breast lymphoma: an uncommon but curable disease. Leuk Lymphoma. 2003; 44:149-51. | Article | PubMed

4. Newman MK, Zemmel NJ, Bandak AZ and Kaplan BJ. Primary breast lymphoma in a patient with silicone breast implants: a case report and review of the literature. J Plast Reconstr Aesthet Surg. 2008; 61:822-5. I Article | PubMed

5. Ryan G, Martinelli G, Kuper-Hommel M, Tsang R, Pruneri G, Yuen K, Roos D, Lennard A, Devizzi L, Crabb S, Hossfeld D, Pratt G, Dell'Olio M, Choo SP, Bociek RG, Radford J, Lade S, Gianni AM, Zucca E, Cavalli F and Seymour JF. Primary diffuse large B-cell lymphoma of the breast: prognostic factors and outcomes of a study by the International Extranodal Lymphoma Study Group. Ann Oncol. 2008; 19:233-41. | Article | PubMed

6. Lyons JA, Myles J, Pohlman B, Macklis RM, Crowe J and Crownover RL. Treatment of prognosis of primary breast lymphoma: a review of 13 cases. Am J Clin Oncol. 2000; 23:334-6. | Article | PubMed

7. Mattia AR, Ferry JA and Harris NL. Breast lymphoma. A B-cell spectrum including the low grade B-cell lymphoma of mucosa associated lymphoid tissue. Am J Surg Pathol. 1993; 17:574-87. | PubMed

8. Jeanneret-Sozzi W, Taghian A, Epelbaum R, Poortmans P, Zwahlen $D$, Amsler B, Villette S, Belkacemi $Y$, Nguyen T, Scalliet $P$, Maingon $P$, Gutierrez C, Gastelblum P, Krengli M, Raad RA, Ozsahin M and Mirimanoff RO. Primary breast lymphoma: patient profile, outcome and prognostic factors. A multicentre Rare Cancer Network study. BMC Cancer. 2008; 8:86. | Article | PubMed Abstract | PubMed FullText

9. Brogi E and Harris NL. Lymphomas of the breast: pathology and clinical behavior. Semin Oncol. 1999; 26:357-64. | PubMed

10. Vitolo U, Seymour JF, Martelli M, Illerhaus G, Illidge T, Zucca E, Campo $E$ and Ladetto $M$. Extranodal diffuse large B-cell lymphoma (DLBCL) and primary mediastinal B-cell lymphoma: ESMO Clinical Practice Guidelines for diagnosis, treatment and follow-up. Ann Oncol. 2016; 27:v91-v102. | Article | PubMed

11. Surov A, Holzhausen H, Wienke A, Schmidt J, Thomssen C and Arnold $D$ et al. Primary and secondary breast lymphoma: prevalence, clinical signs and radiological features. The British journal of radiology. 2014.

12. Colombo D, Bombonati A, Ciocca V and Solin L. Primary Synchronous Bilateral Mucosa-Associated Lymphoid Tissue Lymphoma (MALT) of the Breast: A case Report with Discussion of Management and Review of the Literature. Medical \& Clinical Reviews. 2016.

13. El Hadj O, Gabsi A, Goucha A, Belghith M and Rahal K. Primary Breast Lymphoma: Exceptional Lesion with Particular Management. J Cancer Sci Ther. 2016; 8:294-7. | Pdf

14. Pedrini' JL, Schorr MC, Munaretto MM and Tozatti PV. Non-Hodgkin lymphoma in breast: case report. Rev Bras Mastologia. 2017; 27:61-3. I Pdf

15. Hosein PJ, Maragulia JC, Salzberg MP, Press OW, Habermann TM, Vose $J M$, Bast M, Advani RH, Tibshirani R, Evens AM, Islam N, Leonard JP, Martin P, Zelenetz AD and Lossos IS. A multicentre study of primary breast diffuse large B-cell lymphoma in the rituximab era. $\mathrm{Br} J$ Haematol. 2014; 165:358-63. | Article | PubMed Abstract | PubMed FullText

16. Gholam D, Bibeau F, El Weshi A, Bosq J and Ribrag V. Primary breast Iymphoma. Leukemia \& lymphoma. 2003; 44:1173-8.

17. Aviv A, Tadmor T and Polliack A. Primary diffuse large B-cell lymphoma of the breast: looking at pathogenesis, clinical issues and therapeutic options. Ann Oncol. 2013; 24:2236-44. | Article | PubMed

18. Franco Perez F, Lavernia J, Aguiar-Bujanda D, Miramon J, Guma J, Alvarez R, Gomez-Codina J, Arroyo FG, Llanos M, Marin M, Alfaro J, Quero C, Delgado M, Nogales E, Menarguez F, Martinez N, Torrente M, Royuela A, Abreu D and Provencio M. Primary Breast Lymphoma: Analysis of 55 Cases of the Spanish Lymphoma Oncology Group. Clin Lymphoma Myeloma Leuk. 2017; 17:186-191. | Article | PubMed

19. Ishibashi N, Hata M, Mochizuki T, Ogawa K, Sugiura H, Takekawa $Y$, Maebayashi T, Aizawa T, Sakaguchi M and Abe O. Radiation therapy for primary breast lymphoma in male gynecomastia: a rare case report and review of the literature. Int J Hematol. 2016; 104:519-24. | Article | PubMed

\section{Citation:}

Montazer M, Hoseini M and Farzin H. An unusual manifestation of a breast mass: primary lymphoma. Breast Cancer Rep. 2017; 4:2.

http://dx.doi.org/10.7243/2057-1631-4-2 